\title{
Evaluation of Pedicled Medial Thigh Perforator Flap and Its Application in Loco-Regional Soft Tissue Reconstruction
}

\author{
Wael M. Ayad, Mohamed A. Autifi, Abdel-Nasser M. Khallaf, Ahmed A. Aborawash \\ The Departments of Plastic \& Reconstructive Surgery, Al-Azhar University Hospitals and \\ El-Sahel Teaching Hospital \\ *Correspondence author: Ahmed A. Aborawash, Mobile: (+20) 01066802600, E-mail: ahmedfyounes143@yahoo.com
}

\begin{abstract}
Introduction: perineoscrotal defects represent a challenging problem in reconstructive surgery. Scrotal skin loss can occur following trauma, Fournier's gangrene, post tumor excision, burns, etc. There are many techniques described in the literature for reconstruction of defects of scrotal skin. The pedicled medial thigh (PMT) perforator flap is a valuable reconstructive option. In its pedicled form, the experience is currently limited to a few case reports.

Objective: the purpose of this study was to describe clinical applications of the pedicled medial thigh (PMT) perforator flap for reconstruction of loco-regional soft tissue defects.

Patients and Methods: between June 2018 and June 2019, an experimental cadaveric study including two cadavers with four lower limbs was done in Al-Azhar University, Faculty of Medicine, Department of Anatomy and Embryology. A prospective cross-sectional study in which ten male patients with soft tissue defects or lesions that requires excision and reconstruction in perineum and scrotum received MTP flaps. All flaps were unilateral and the flap sizes ranged from 9-12 cm to $12-26 \mathrm{~cm}$. Results: all flaps survived well, with the exception of partial wound dehiscence in two patients that was managed conservatively by frequent dressings and healed by 2ry intention.

Conclusion: the medial thigh fasciocutaneous perforator flap offers a good option for Perineoscrotal defects. The flap provides a single stage, stable, well vascularized soft tissue coverage with no significant major complications, short hospital stay, appropriate range of motion, faster return to normal lifestyle and accepted aesthetic appearance.
\end{abstract}

Keywords: Pedicled Medial Thigh Perforator Flap, Application in Loco-Regional Soft Tissue Reconstruction.

\section{INTRODUCTION}

Perineoscrotal defects represent a challenging problem in reconstructive surgery. Etiologies include traumatic avulsion of scrotal skin, burn injury, tumor ablation, and infection. Fournier's gangrene is an acute and potentially lethal necrotizing fasciitis that involves the skin and soft tissues of the scrotum, perineum, and lower abdomen, resulting in tissue defect, and possibly death. After adequate surgical debridement and infection control, the remaining skin and soft tissuedefects need to be covered ${ }^{(\mathbf{1})}$.

There are many techniques described in the literature including residual scrotal skin mobilization for defects of scrotal skin up to 50\%, split skin graft, thigh flaps with pouch, tissue expansion, gracilis myocutaneous advancement flap, groin fasciocutaneous island flap, flaps based on inferior epigastric vessels, superomedial thigh flaps, pedicled omental flap and even microvascular free greater omentum flap ${ }^{(1)}$.

The pedicled medial thigh (PMT) perforator flap is a valuable reconstructive option. In its pedicled form. The experience is currently limited to a few case reports. The purpose of this study was to describe clinical applications of the pedicled medial thigh (MTP) perforator flap for reconstruction of loco-regional soft tissue defects ${ }^{(\mathbf{1})}$.

\section{AIM OF THE WORK}

Aim of this study is to evaluate the validity and application of pedicled medial thigh perforator flap for loco-regional soft tissue reconstruction of the groin and

perineum region and assessment of aesthetic and functional outcome of using this flap.

\section{PATIENTS AND METHODS}

A prospective cross sectional study involving 10 patients with soft tissue defects or lesions that requires excision and reconstruction in the proximal and distal medial thigh, groin, perineum and genitalia (scrotum \& vulva). The study was carried on Plastic Surgery Departments, Al-Hussien \& Bab Elshaaria Hospitals, Faculty of Medicine, Al-Azhar University (Cairo) in the period between June 2018 and June 2019. Medial thigh perforator flap was performed for ten male adult patients. Their mean age was 48.8 ( $36-63$ years) years old. All patients presented with soft tissue defects of the scrotal and perineal areas after extensive multiple debridement sessions for Fournier's gangrene (8 patients) and two patients with raw area in the scrotum after excision of a huge condyloma accuminata lesion.

\section{Inclusion criteria:}

- Male and female patients

- All patients older than 5 years old

- Patients with soft tissue defects in the thigh, groin, perineum

- Scrotal reconstruction after debridement of Fournier's gangrene

- Scrotal, penile or vulvar lesions that require reconstruction after excision

- Chronic resistant groin Hidradenitis Suppurativa

- Local post burn contracture

- Local unstable scar.

\section{Exclusion criteria:}

- Patients not fit for surgery

- Diseased donor site

- Psychologically unstable patients

- Bleeding tendency 
- Minor problems that can be managed by simple procedures.

\section{Ethical Consideration}

An approval of the study was obtained from Al- Azhar University Academic and Ethical Committee. Every patient signed an informed written consent for acceptance of the operation.

\section{MANAGEMENT}

A. After diagnosing a necrotizing soft tissue infection, there were three required components of management.

1. Resuscitation

2. Broad spectrum IV antibiotic administration

3. Emergent radical surgical debridement

\section{B. Antibiotic coverage}

1. Broad coverage should be used until microbiologic analysis of the wound is available.

\section{Radical surgical debridement}

1. Immediate operative debridement.

2. Debridement of all necrotic tissues with intraoperative quantitative culture and biopsy specimens. Wound fluid gram staining should be performed.

3. Debridement should be extended to viable tissue, with possible extremity amputation in clostridial gangrene.

4. Postoperative intensive care is usually required.

5. Repeated exploration in 24 to 48 hours is performed, and remaining infected tissue is excised.

\section{Preoperative preparation}

A. Investigations:

1. Routine labs.

2. Electrocardiogram (ECG).

3. Chest x-ray.

B. Prophylactic Antibiotic Regimen

\section{Preoperative photography}

The surgical procedure is done under general anesthesia with oral intubation or spinal anesthesia with sedation in supine position, Urinary catheter is inserted.
The MTP flap is based on musculocutaneous perforators originating from the superficial femoral vessel and passing through the medial thigh musculature to supply the skin of the inner aspect of the thigh. The flap is marked with the patient supine and the leg rotated laterally with hip and knee flexed. The femoral triangle is the anatomical landmark indicating the site of the flap perforators proximal to the adductor canal from the medial side of the superficial femoral artery. A straight line ' $A$ ' extending from the anterior superior iliac spine (ASIS) to the medial femoral epicondyle. A second line ' $\mathrm{B}$ ' is drawn from the midpoint of the inguinal ligament to the central point of the patella. The intersection of lines ' $A$ ' and ' $\mathrm{B}$ ' indicates the central locus ' $\mathrm{C}$ ' of the medial thigh flap perforators' scope. The flap is designed as a longitudinal ellipse centered at ' $C$ '. The majority of perforators are detected using a hand held Doppler on a line $10 \mathrm{~cm}$ proximal and distal to point ' $\mathrm{C}$ ' (Fig. 1A). The flap is raised by incising the lateral margin in a subfascial plane and identifying suitable perforators. Rectus femoris and Sartorius muscles are retracted laterally to ease visualisation of the pedicle proximally and identify perforator origin at the superficial femoral artery (Fig. 1B). Once flap vascularity has been identified, the medial margin of the flap became free and the flap was raised using standard techniques of perforator flap harvest, namely meticulous musculocutaneous perforator dissection and scrupulous haemostasis (Fig. 1C).

The type of flap in 6 patients $(60 \%)$ were pedicled perforator while 4 patients $(40 \%)$ were island perforator. The donor site was closed primarily in all cases, operative time ranged from $150-170 \mathrm{~min}$ and all flaps were unilateral. Broad spectrum systemic antibiotics were given and continued for 5 days postoperatively. Flap sizes ranged from $9 X 12 \mathrm{~cm}$ to $12 \times 26 \mathrm{~cm}$. The follow-up period was from 3 to 11 months.

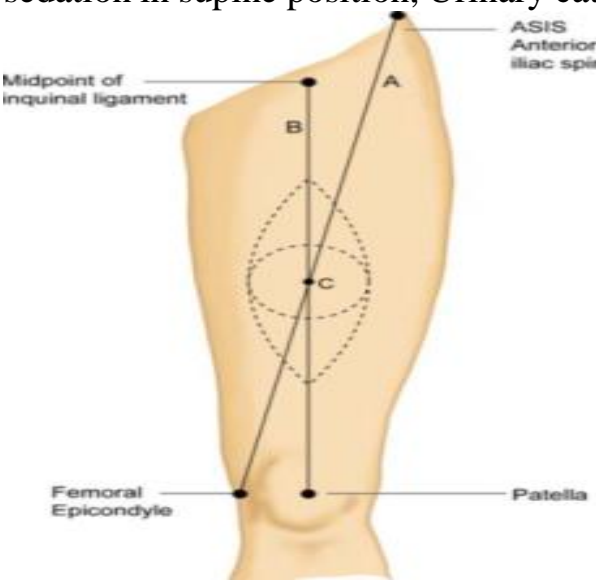

(A)

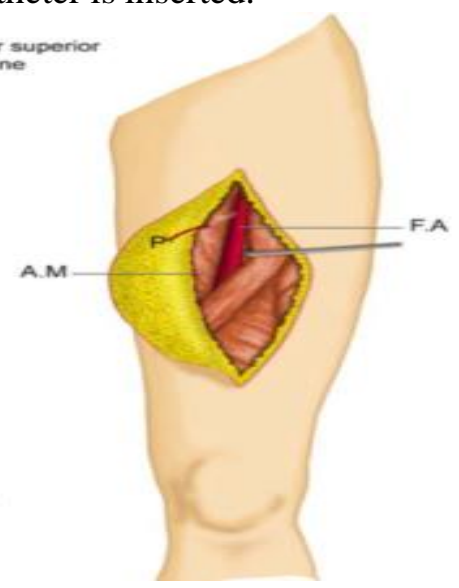

(B)

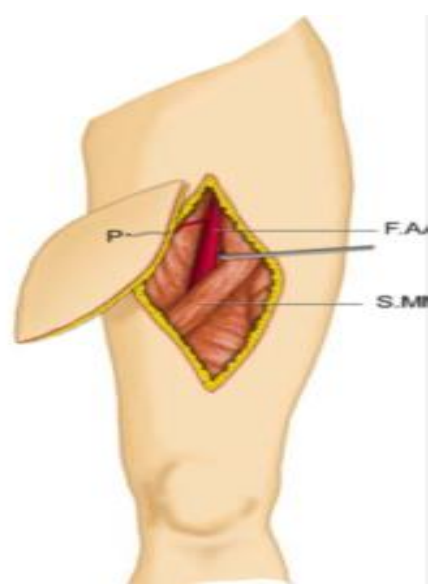

(C)

Figure (1): The schematic demonstration of the harvesting method of the medial thigh (MT) perforator flap. (A) Design mark of the MT perforator flap. (B) Identifications of adequate perforators from lateral margin of the flap, superficial femoral artery (S.F.A.), adductor magnus (A.M.) muscle, satorius muscle (S.M.). (C) Intramuscular dissection ${ }^{(2)}$. 


\section{Statistical analysis}

Recorded data were analyzed using the statistical package for social sciences, version 20.0 (SPSS Inc., Chicago, Illinois, USA). Quantitative data were expressed as mean \pm standard deviation (SD). Qualitative data were expressed as frequency and percentage.

\section{The following tests were used:}

- Independent-samples t-test of significance was used when comparing between two means.

- Chi-square $\left(\mathrm{x}^{2}\right)$ test of significance was used in order to compare proportions between two qualitative parameters.

- The confidence interval was set to $95 \%$ and the margin of error accepted was set to $5 \%$. The p-value was considered significant as the following:

- Probability (P-value)

$\mathrm{P}$-value $<0.05$ was considered significant.

$\mathrm{P}$-value $<0.001$ was considered as highly significant.

$\mathrm{P}$-value $>0.05$ was considered insignificant.

\section{Results}

Table (1): Cadaveric Data and Measurement Results

\begin{tabular}{|l|c|c|c|c|c|}
\hline Cadever Side & $\begin{array}{c}\text { Distance } \\
\text { from } \\
\text { midpoint } \\
\text { of } \\
\text { ing.lig to } \\
\text { MTF } \\
\text { perforator } \\
\text { (cm) }\end{array}$ & $\begin{array}{c}\text { Distance } \\
\text { from } \\
\text { midpoint } \\
\text { of } \\
\text { ing.lig to } \\
\text { MTF } \\
\text { perforator } \\
\text { (cm) }\end{array}$ & $\begin{array}{c}\text { Length } \\
\text { of } \\
\text { pedicle } \\
\text { (cm) }\end{array}$ & $\begin{array}{c}\text { Type of } \\
\text { perforator }\end{array}$ & \\
\hline 1 & Rt & 19 & 20 & 6 & $\begin{array}{l}\text { Musculo- } \\
\text { cutaneus }\end{array}$ \\
\hline 1 & Lt & 18 & 21 & 6.5 & $\begin{array}{l}\text { Musculo- } \\
\text { cutaneus }\end{array}$ \\
\hline 2 & Rt & 17 & 19 & 5.5 & $\begin{array}{c}\text { Septo- } \\
\text { cutaneus }\end{array}$ \\
\hline 2 & Lt & 16 & 18 & 5 & $\begin{array}{c}\text { Septo- } \\
\text { cutaneus }\end{array}$ \\
\hline & & & & & \\
\hline
\end{tabular}

This table showerd the anatomical details of the cadaveric dissection of four lower limbs regarding the anatomical site of flap perforator and distance to static anatomical landmark and type of perforator detected clinically.

Table (2): Description of age in studied patients

\begin{tabular}{|l|c|c|}
\hline \multirow{2}{*}{ Variables } & $\begin{array}{c}\text { Studied patients } \\
(\mathbf{N}=\mathbf{1 0})\end{array}$ \\
\hline \multirow{4}{*}{ Age (years) } & Mean & 48.8 \\
\cline { 2 - 3 } & $\mathbf{\pm S D}$ & 9.81 \\
\cline { 2 - 3 } & Min & 36 \\
\cline { 2 - 3 } & Max & 63 \\
\cline { 2 - 3 } & Range & $(36-63)$ \\
\hline
\end{tabular}

This table showed the description of age in studied patients. The mean of age of studied patients was $48.8 \pm 9.81$ years old with minimum age of 36 years and maximum age of 63 years (range $36-63$ ). All studied patients were males $(100 \%)$.
Table (3): Description of diagnosis in studied patients

\begin{tabular}{|c|c|c|}
\hline \multicolumn{2}{|c|}{ Variables } & $\begin{array}{c}\text { Studied } \\
\text { patients } \\
(\mathbf{N}=10)\end{array}$ \\
\hline \multirow{2}{*}{ Diagnosis } & post fournier's gangrene & $8(80 \%)$ \\
\cline { 2 - 3 } & $\begin{array}{c}\text { post excison of scrotal } \\
\text { condyloma accuminata }\end{array}$ & $2(20 \%)$ \\
\hline
\end{tabular}

This table showed the description of diagnosis in studied patients. 8 patients $(80 \%)$ were post fournier's gangrene while 2 patients (20\%) were post excison of scrotal condyloma accuminata.

Table (4): Description of flap complications in studied patients

\begin{tabular}{|c|c|c|}
\hline \multirow{2}{*}{ Variables } & $\begin{array}{c}\text { ptudied patients } \\
(\mathbf{N}=10)\end{array}$ \\
\hline $\begin{array}{c}\text { Flap } \\
\text { complications }\end{array}$ & $\begin{array}{c}\text { Negative } \\
\text { Partial wound } \\
\text { dehiscence }\end{array}$ & $8(80 \%)$ \\
\hline
\end{tabular}

This table showed the description of flap complications in studied patients. 8 patients $(80 \%)$ had no flap complications while 2 patients $(20 \%)$ had partial wound dehiscence (they were managed until healing by 2ry intention).

Table (5): Description of donor site complications in studied patients

\begin{tabular}{|c|c|c|}
\hline \multirow{2}{*}{ Variables } & $\begin{array}{c}\text { Studied patients } \\
(\mathbf{N}=10)\end{array}$ \\
\hline \multirow{2}{*}{$\begin{array}{c}\text { Donor site } \\
\text { complications }\end{array}$} & $\begin{array}{c}\text { Negative } \\
\text { Partial wound } \\
\text { dehiscence }\end{array}$ & $8(80 \%)$ \\
\hline
\end{tabular}

This table showed the description of donor site complications in studied patients. 8 patients $(80 \%)$ had no complications while 2 patients $(20 \%)$ had partial wound dehiscence (they were managed until healing by 2ry intention).

Table (6): Description of follow up time in studied patients

\begin{tabular}{|c|l|c|}
\hline \multicolumn{2}{|c|}{ Variables } & $\begin{array}{c}\text { Studied patients } \\
(\mathbf{N}=10)\end{array}$ \\
\hline \multirow{3}{*}{$\begin{array}{c}\text { Follow up } \\
\text { time }\end{array}$} & 3 months & $4(40 \%)$ \\
\cline { 2 - 3 } & 4 months & $2(20 \%)$ \\
\cline { 2 - 3 } & $\mathbf{1 0}$ months & $2(20 \%)$ \\
\hline
\end{tabular}

This table showed the description of follow up time in studied patients. 4 patients $(40 \%)$ were followed up for 3 months, 2 patients (20\%) were followed up for 4 months, 2 patients $(20 \%)$ were followed up for 10 months and 2 patients (20\%) were followed up for 11 months. 
Table (7): Description of post-operative clinical assessment in studied patients

\begin{tabular}{|c|c|c|}
\hline \multirow{2}{*}{ Variables } & $\begin{array}{c}\text { Studied } \\
\text { patients } \\
(\mathbf{N}=\mathbf{1 0})\end{array}$ \\
\hline \multirow{2}{*}{$\begin{array}{c}\text { Flap } \\
\text { temperature }\end{array}$} & Warm (good) & $10(100 \%)$ \\
\cline { 2 - 3 } & Hot (venous congestion) & $0(0 \%)$ \\
\cline { 2 - 3 } Flap color & Cold (arterial ischemia) & $0(0 \%)$ \\
\cline { 2 - 3 } & Normal (good) & $10(100 \%)$ \\
\cline { 2 - 3 } & Pale (venous congestion) & $0(0 \%)$ \\
\hline \multirow{2}{*}{$\begin{array}{c}\text { Capillary } \\
\text { filling }\end{array}$} & $\mathbf{2}$ sec (good) & $0(0 \%)$ \\
\cline { 2 - 3 } & < 2 sec (venous congestion) & $0(100 \%)$ \\
\cline { 2 - 3 } & $>\mathbf{2 ~ s e c ~ ( a r t e r i a l ~ i s c h e m i a ) ~}$ & $0(0 \%)$ \\
\hline
\end{tabular}

This table (7) showed the description of postoperative clinical assessment in studied patients. All studied patients (100\%) showed warm flap temperature, normal flap color and normal capillary filling.
All flaps survived well, with the exception of partial wound dehiscence in two patients, which was managed conservatively by frequent dressings and healed by 2ry intention. Infection and partial wound dehiscence of the donor site suture line occurred in two cases which managed by frequent dressings.

\section{Clinical Cases}

Case 1: 57 years old male patient presented with raw area in scrotum \& perineum after excision of condyloma accuminata (A), Design of MTP flap after detecting suitable perforator with hand held doppler (B), Dissection started lateral to medial in subfascial plain till identification of 4 septocutaneous perforators, ligation of distal 3 perforators (C), Rotation of flap 90 degrees, insetting of flap, insertion of rubber drain in flap site, suction drain in donor site (D). (Fig.2)

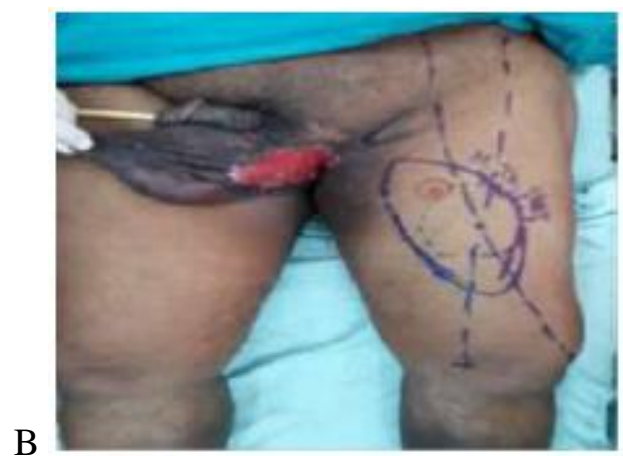

A

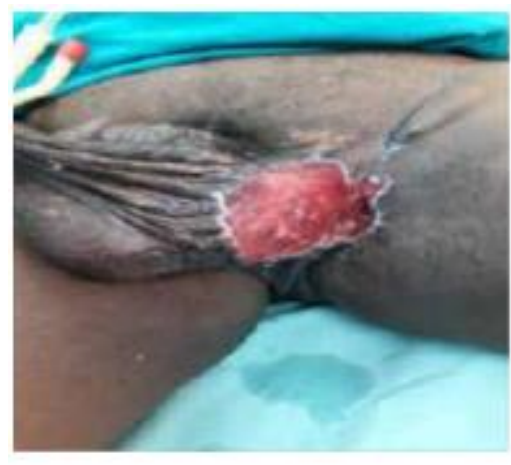

$\mathrm{C}$

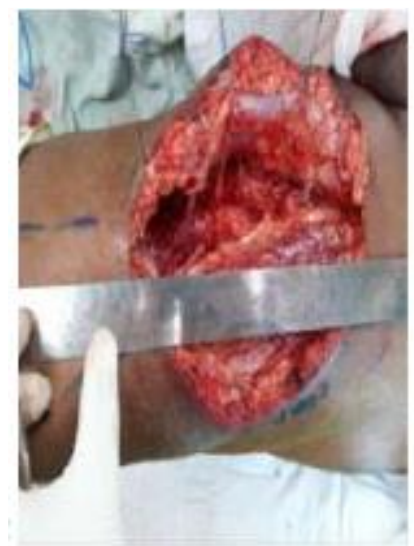

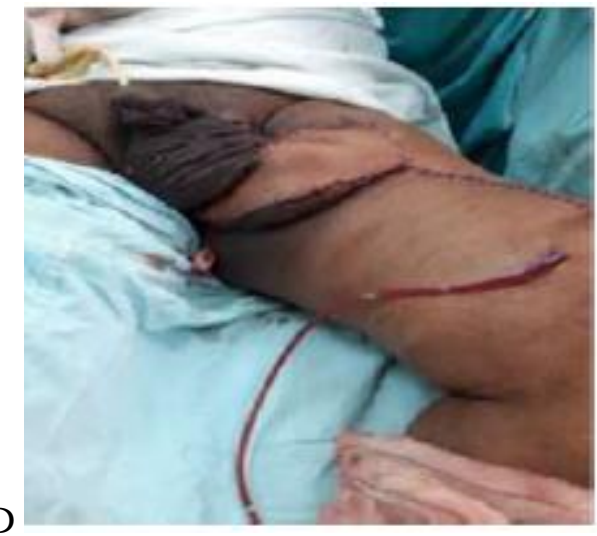

Case 2: 47 years old male patient presented with raw area in scrotum, perineum after fourniere's gangrene (A), Design of MTP flap after identifying appropriate perforator (B), dissection of flap and identifying septocutaneous perforators (C), Insetting of MTP flap (D), 1st day postoperative (E), 2 weeks postoperative (F).(Fig.3) 


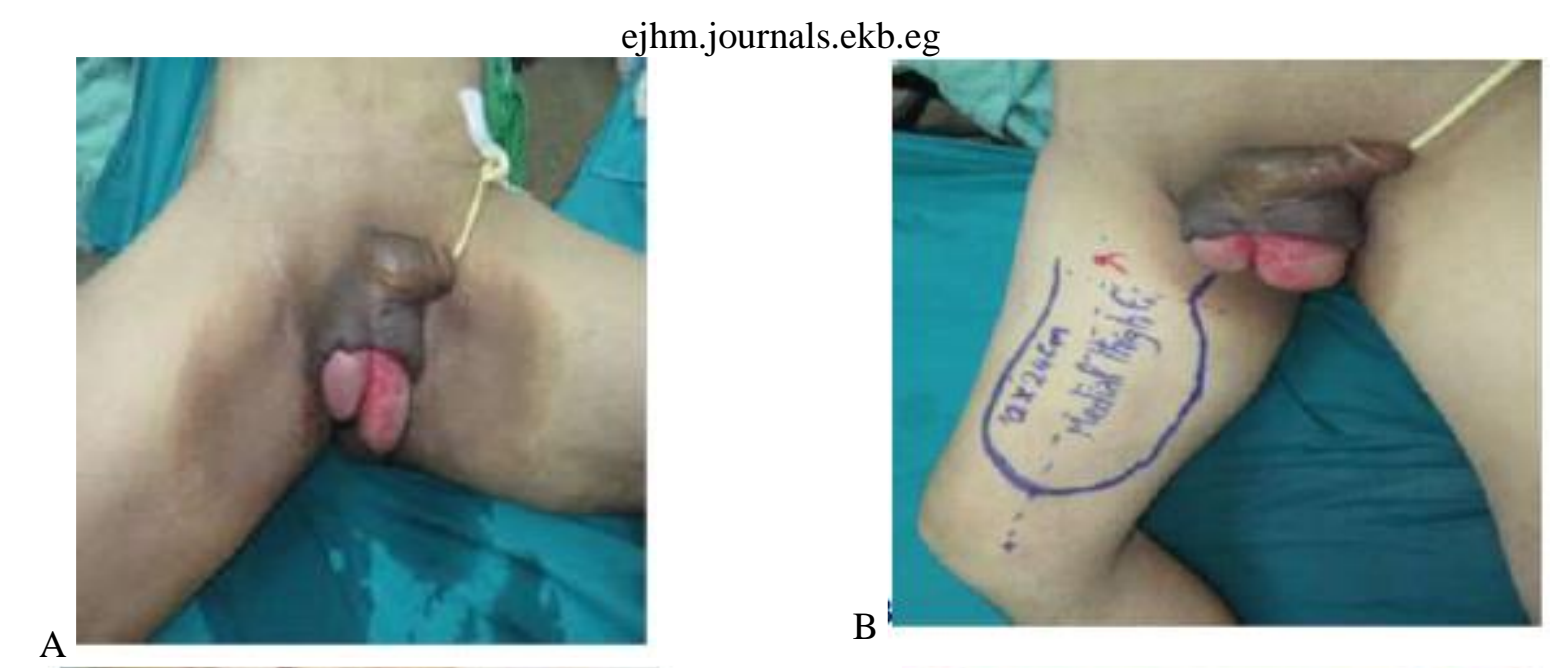

C
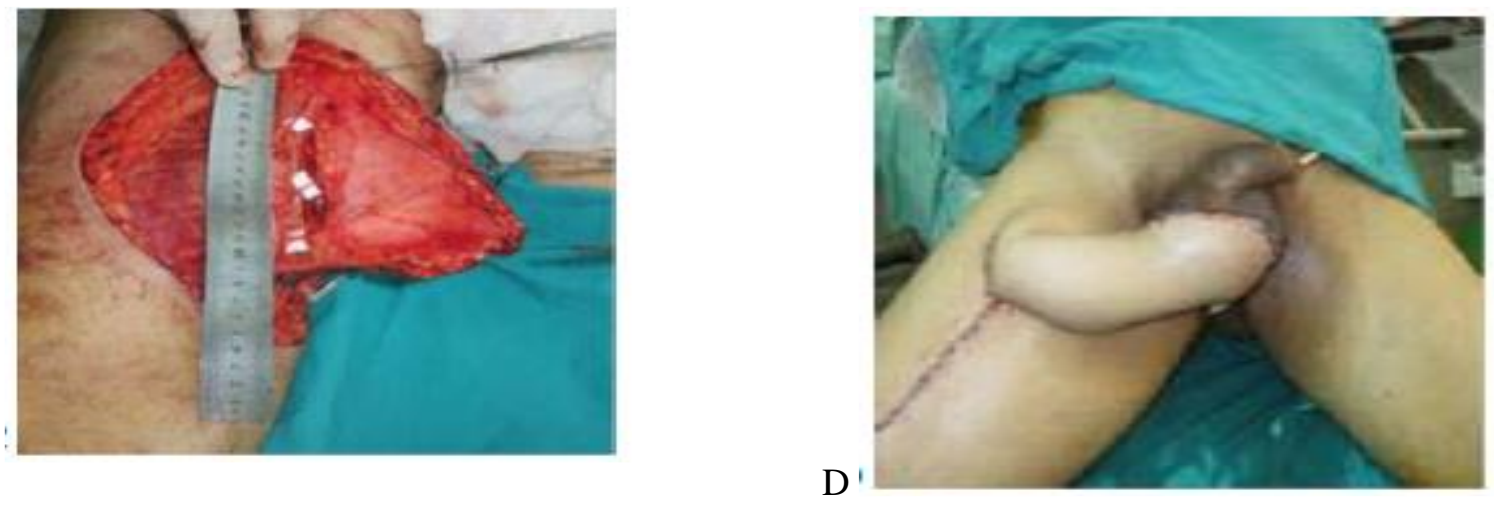

\section{DISCUSSION}

Yu et al. (3) used the anterolateral thigh fasciocutaneous island flap in Perineoscrotal reconstruction. This is more difficult to dissect, more bulky and it's far from the defect.

The medial thigh flap was first described by Baek et al. $^{(4)}$ and applied originally in the reconstruction of pelvic and sacral deformities and post-burn groin scar contracture by Hallock et al. ${ }^{(5)}$.

Wang et al. ${ }^{\left({ }^{(6)}\right.}$ have described in detail the vascular supply and innervation of the medial thigh fasciocutaneous flap. They found two to four constant perforators to the MT flap that were easy to identify and they described its use when turned medially for vaginal and perineal reconstruction and when turned laterally for groin reconstruction.

Turley et $\boldsymbol{a l} .{ }^{(7)}$ have transposed the flap medially and used it to cover scrotal, penile, perineal and proximal thigh defects. The exact limitations on width and length of the flap are unknown, but the rich suprafascial plexus in this area allows safe elevation of flaps with a 3:1 length-to-width ratio with largest flap measured approximately $9 \mathrm{X} 17 \mathrm{~cm}$.

Chung et al. ${ }^{(2)}$ used the free MTP flap based on septocutaneous vessels or musculocutaneous perforators originating from the superficial femoral vessel and passing through the medial thigh musculature to supply the skin of the inner aspect of the thigh for reconstruction of the dynamic and static complex burn scar contracture of eight patients.

The current study aimed at evaluating the result of application of pedicled medial thigh perforator flap for loco-regional soft tissue reconstruction. The sample size in our prospective study was $\mathbf{1 0}$ male patients, which was considered suitable when compared with other prospective studies like Wael et al. ${ }^{(8)}$, which included seven male patients. The mean age of studied patients was $48.8 \pm 9.81$ years old (range $36-63$ years), which is compatible with Wael $\boldsymbol{e t} \boldsymbol{a l} .{ }^{(8)}$ in which their mean age was 42 (range 33 to 52 years).

In the current study, All male patients suffered from perineoscrotal soft tissue defects, 8 patients (80\%) were post fournier's gangrene while 2 patients $(20 \%)$ were post excison of scrotal condyloma accuminata. While, in Wael et al. ${ }^{(8)}$, all patients presented with soft tissue defects of the scrotal and perineal areas after extensive multiple debridement sessions for Fournier's gangrene.

In the current study, ten unilateral fasciocutaneuos flaps done, six of them raised in the form of pedicled perforator flaps and four island perforator flaps. In Wael $\boldsymbol{e t}$ al. ${ }^{(8)}$ nine medial thigh fasciocutaneuos flaps were performed (five unilateral and two bilateral), all were in pedicled form.

In the current study, Operative time was $158 \pm$ $7.89 \mathrm{~min}$ with minimum time of $150 \mathrm{~min}$ and maximum time of $170 \mathrm{~min}$. Operative time not reported in Wael $\boldsymbol{e t}$ al. ${ }^{(8)}$.

In the current study, 8 patients ( $80 \%$ ) had no flap complications while 2 patients (20\%) had partial wound dehiscence (they were managed conservatively by frequent dressings and healed by 2ry intention). While, in Wael et al. ${ }^{\left({ }^{(8)}\right.}$ all flaps survived well, with the exception of partial distal necrosis in two cases. This 
was managed conservatively in one case, while the other case needed debridement and minimal advancement of the flap.

In the current study, 8 patients $(80 \%)$ had no donor site complications while 2 patients $(20 \%)$ had partial wound dehiscence (they were managed conservatively by frequent dressings and healed by 2ry intention. while in Wael $\boldsymbol{e t}$ al. ${ }^{(8)}$, infection of the donor site suture line occurred in one case which managed by frequent dressing.

As regard follow up period, 4 patients (40\%) were followed up for 3 months, 2 patients (20\%) were followed up for 4 months, 2 patients (20\%) were followed up for 10 months and 2 patients $(20 \%)$ were followed up for 11 months. while in Wael et al. ${ }^{(8)}$, patients were followed for 3-18 months postoperatively.

As regard the flap size of studied patients was width of the flap ranged from $9-12 \mathrm{~cm}$, while the length ranged from $19-26 \mathrm{~cm}$ and the donor side was closed directly in all cases. While in Wael et al. ${ }^{(\mathbf{8})}$, the width of the flap ranged from $7-10 \mathrm{~cm}$, while the length ranged from $17-25 \mathrm{~cm}$ and the donor side was closed directly in all cases.

In this study, Debulking of 2 flaps (20\%) was done upon patient's request by flap elevation and tissue excision. flap debulking not reported in other studies.

Patient satisfaction in the studied patients; 6 patients $(60 \%)$ were very good, 2 patients $(20 \%)$ were good and 2 patients $(20 \%)$ were excellent. Assessment was done according to several factors like hospital stay, healed wounds, range of motion, return to normal lifestyle and aesthetic appearance.

The advantages of the MTP flap for reconstruction of perineoscrotal defects include: (1) soft and pliable hairless flap, (2) short harvesting time, (3) numerous perforators contributing to broad skin territory, (4) ability to connect with neighbouring thigh flaps (free anteromedial thigh flap, tensor fascia lata flap and ALT flap), (5) potential to incorporate the great saphenous vein as a venous graft or additional venous drainage route and (6) ability to neurotise the flap ${ }^{(9)}$.

The relative disadvantages of the MTP flap cited in the literature include the relatively short, small- diameter pedicle and potential bulkiness of the fat of the medial thigh ${ }^{(9)}$.

\section{CONCLUSION}

The medial thigh fasciocutaneous perforator flap offers a good option for Perineoscrotal defects. The flap provides a single stage, stable, well vascularized soft tissue coverage with no significant major complications, short hospital stay, appropriate range of motion, faster return to normal lifestyle and accepted aesthetic appearance.

\section{REFERENCES:}

1- Mario FS, Alberto F, Pietro G (2018): A Pedicled posteromedial thigh (pPMT) perforator flap and its application in locoregional soft tissue reconstructions. Journal of Plastic, Reconstructive \& Aesthetic Surgery, 71: 217-223.

2- Chung HF, Yung JY, Shiow SC (2010): Free medial thigh perforator flap for reconstruction of the dynamic and static complex burn scar contracture. Burns, 36: 565-571.

3- Yu P, Sanger JR, Matloub HS et al. (2002): Anterolateral thigh fasciocutaneous island flaps in perineoscrotal reconstruction. Plast Reconstr Surg., 109: 610-616.

4- Baek SM (1983): Two new cutaneous free flap, the medial, and lateral thigh flaps. Plast Reconstr Surg., 71: $354-65$.

5- Hallock GG (1990): Scrotal reconstruction following Fournier's gangrene using the medial thigh fasciocutaneous flap. Ann Plast Surg., 24: 86-90.

6- Wang T, Whetzel T, Mathes SJ et al. (1987): Fasciocutaneous flap for vaginal and perineal reconstruction. Plast Reconstr Surg., 80: 95-102.

7- Turley CB, Cutting P, Clarke JA (1991): Medial fasciocutaneous flap of thigh for release of post-burn groin contractures. Br J Plast Surg., 44: 36-40.

8- Wael MA, Osama AA, Ehab $Z$ et al. (2011): The Versatility of the Medial Thigh Flap for Reconstruction of Post-Fournier's Gangrene Complex Perineoscrotal Defects. Egypt J Plast Reconstr Surg., 35 (1): 129-132.

9- Koshima I, Hosoda M, Inagawa K (1996): Free medial thigh perforator-based flaps: new definition of the pedicle vessels and versatile application. Ann Plast Surg., 37: $507-15$. 